\title{
Employee Branding and Talent Acquisition- an Imperative Need
}

\author{
Renu Rathi, Usha S
}

\begin{abstract}
- within the triumphing enterprise age, affiliations want to rehash and to rethink themselves at an important stage and to come to be agiler. advancement of HR the officers proposes a circulate from massive mindset on place of business closer to duty, gaining knowledge of and improvement of marketers and task for capability. The belief driving this examination is to study the affiliation between the worker Branding and expertise Acquisition. The expressive research configuration is used for the present paintings. An top notch inspecting has been used to deliver collectively the facts. The individuals inside the review are $180 \mathrm{HR}$ directors of picked IT groups in Bangalore. The device used for statistics aggregation is a self-specific,self-figured and organized poll. After the assessment, it very well can be presumed that worker Branding decidedly impacts talent Acquisition. The examination famous that in an open ability economic machine, business enterprise emblem is noteworthy in deciding on and maintenance, and protection of excessive functionality experts and should be revolved around gaining knowledge of and administration development, adaptability, prizes and competency systems. A part of the inspiration reliant on the exam is also shown in this paper.
\end{abstract}

Keywords - employee, Branding, skills Acquisition, impact, courting.

\section{INTRODUCTION}

worker marking essentially proposes what an agent wearing activities approximately himself and the association subculture. A sturdy perception of association, sentiment of association is visible of the laborer in the course of his/her affiliation. He/She want to have the alternative to fill in as a brand represetative for his/her organizationIn essential phrases, employees standpoint and responsibility inside the direction of the association photo is superior thru the way of life of the affiliation. The employee marking contains the 4 fundamental matters as an instance via the use of explicit securing/specific enlistment, giving concentrated on planning/affirmations to human beings, efficiently bestowing the company objectives and what is regular, artwork readability and the repayment device should intertwine messages that dependably and as regularly as achievable reflect the emblem and hierarchical picture.

The employee marking is comparable phrase articulation of skills management alongside the ones traces the consultant marking through talent the board for consumer determination may be accurately performed with the useful resource of thoroughly focusing on skills control. it's miles on a very fundamental diploma constituent of five segments: attracting, deciding on, drawing in with, making and keeping down personnel and it's far in standard pressured

Revised Manuscript Received on September 14, 2019.

Dr.RenuRathi, AssociateProfessor, Jain (Deemed to be) University Jayanagar, Bengaluru, Karnataka, India. (E-mail renuashishrathi@gmail.com)

Dr. Usha S, AssociateProfessor, Jain (Deemed to be) University Jayanagar, Bengaluru, Karnataka, India.. (E-mail: ushabhs@gmail.com) over perceiving the functionality, progression arranging, retaininghighly expert and key sellers via the usage of aggregate of physical games in addition as knowledge specific systems. representative's records health and restriction are noteworthy guns which offers immoderate floor to the association in awful mission.

in recent times of dynamic organization, nature of $\mathrm{HR}$ is increasing an super limit with regards to constructing a strong various leveled image to collect success.Ever extending openings in artwork exhibit have given an numerous choices for the motion wannabes to investigate numerous roads in regards to them. Of direction, the affiliations are doing preventing a ton to draw and keep the capacity. They need to bestow to the outdoor global approximately their provide which solidifies ethos, way of life, admire structure, thriving and future ability outcomes to pull in limit.

\section{METHODOLOGY}

the ones associations which venture themselves as the incredible place of business and supervisor can attract the capability and furthermore decline enduring loss of professional group of workers. potential the board delineates an artwork of functionality acquisition and renovation which might be essential quantities of HRM. there are various devices which are used by the institutions in pulling in choosing, interfacing with and preserving the important thing affords. On severa occasions, the various gadgets and methods used for the plan are short and the institutions land up pulling in an appropriate potential with wished amount

\section{Writing review}

The duration, fine, sum, packaging, concealing, restricted time blessings, and so on are the distinct strategies utilized by the institutions to ruin inside the clients to their devices and administrations. In like manner, business company electricity, forceful remuneration percent, flexi working hours, getting ready and improvement applications, proficient fulfillment, worrying situations, novel possibilities, sensible evaluation of execution, legitimate subculture, etc., are deliberately used to pull in, manipulate and maintain the important thing talented representatives one of such modern HR devices for ability acquiring and guide now-a-days being used by the institutions is boss marking. Boss marking is decently a few different effective area within the executives inquire approximately.

The accompanying examination indicates the research on supervisor marking and capability the executives in two regions: section 1: organization Branding and segment 2: 
expertise management section 1: business enterprise Branding: atfirst Ambler and Barrow (1996) are the number one to companion the HR the board and brand the board in case you want to make a hypothetical structure which they call the "business emblem'. They depict supervisor marking as -the heap of beneficial, money associated and intellectual opportunities gaven byemployment, and associated with the use of employer. In a hypothetical paper, Backhaus and Tikoo (2004) consolidate boss marking as - the technique of constructing an unmistakable and putting organiztaional persona and the economic enterprise emblem as an idea of the firm that isolates it from one in all a type contenders.

Aaker. A.D. (1991), in his article titled "Overseeing complemented that organization marking is the effect that a emblem call motivates within the cerebrums of purchasers. The emblem affiliations may be estimated with reference to smell, taste, or distinctive sensation or feeling approximately the logo. $\log$ o affiliations are the determinants of brand photo that it's far an amalgamation of the thing/non-issue associated developments, and the feasible/huge favorable activities fused in the emblem affiliations that live in purchaser memory (MagneSupphellen, 2000). The object related characteristics portray the unmistakable desires of the matters and relate them to precious favorable times got from using such devices/management. Non-item related characteristics cope with the highbrow imagery and determinations of the clients approximately item, these homes fulfill the necessities and wishes for the clients contrasting with meaningful advantages.

As defined by Richard W. Mosely (2007), the use of supervisor marking to increase an outer notoriety, with genuinely pressured usage of the term to depict internal attempts to electricity first-rate commercial enterprise obligation or culture alternate. The hassle is mergeof boss marking as an umbrella which manages capability the board. Cooper, okay (2008), identifiedemployer marking as what an association to provide its people. Boss marking can be used as a device to manipulate the care and impact of people, capability delegates and associated accomplices as to specific affiliation.

Pallavi and JyotsnaBhatnagar (2010), in their paper on "supervisor logo for skills Acquisition: An Exploration towards its size', deal with the trouble of ability the executives thru boss marking. Key functionality buying is the final results of manager marking. The enterprise marking is settled through profession development, compensation processes, individualsorientedness, mastering and improvement of an business enterprise. these components of the organization marking, are delegated a minding and attractive association. The portions of what the affiliation is and what the affiliation has for its humans are the noteworthy essential factors of business marking

the standard record by means of using Deloitte (2012) said that critical potential is getting continuously tough to replace in view of absence of capable experts to be had inside the art work exhibit. on this manner, the report suggests that ability the executives need to pursue divided method as the preference for representatives contrasts as consistent with a long term, land place, sexual orientation, emblem equity: Capitalizing on the fee of a logo call"'

and so on. It modified into located that millennial' andgeneration $X^{\prime}$ anticipate budgetary motivations and advancements, even as children of put up warfare the us's want backing and acknowledgment. It become likewise placed that men appeared to pay interest on coins related motivations, while women were sure to search for acknowledgment.

\section{2. goals OF examine}

a. To observe the tremendous strategies of employee marking completed by the IT groups in Bangalore

b. To conceptualize the relationship between the worker Branding and skills Acquisition

3. studies method

research design:

The form of studies embraced is elucidating research as this exploration includes examine and reality coming across enquiries to differentiate the relationship most of the employee Branding and talent management on the IT agencies in Bangalore.

\section{Theoretical Framework}

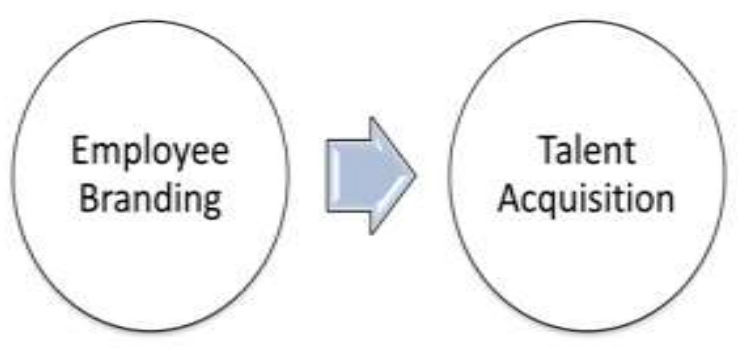

\section{Variables of Study}

- worker fee Proposition (EVP): EVP provide gift and future employeesmotivation paintings for commercial enterprise and aggressive gain of businesses mirror. EVP boss associated with them controlled to enjoy the enlargement inside the pool of talent and commitment in their people, just as payroll value discount ability. by analyzing the variables impacting enterprise logo, and by means of characterizing EVP solid and original, organizations may have the choice to deliver voice and correspondence stable over the degree and build an interesting correspondence, along with appealing, emblem managers.

- worker - organization relations: The employees in the organisation given the liberty to take part in sharing emotions and engage with a good sized base management of the affiliation. It also will enhance family members representatives boss

- recognition \& creative environment in the place of work: worker achievement inside the business enterprise need to be publicly rewarded with store the month or sector put bulletins on the wall of repute. this will motivate different personnel as properly and crates friendly and aggressive environment

- employees as logo ambassadors: employees must talk

Published By:
Blue Eyes Intelligence Engineering

\& Sciences Publication 
virtually to all employees, Transparency in all procedures must be preserved

- Succession making plans: Therecruitment and merchandising policy need to be very clear, obvious and have to make certain ideal. this will help in proper planning expertise acquisition and succession making plans is also essential and key positions.

- feedback on Recruitment technique: The recruitment manner should be time framed and need to be an choice to alternate if essential primarily based on remarks with the aid of stakeholders.

- schooling \& improvement: The business enterprise is a plan for schooling and improvement wishes of employees with right identity of the schooling wishes based at the talents hole.

\section{design sample:}

$\square$ population: The population for this examine included the HR manager of ITcompanies in Bangalore.

$\square$ sample length: 180

Examples $\square$ techniques: A convenient pattern become used to gather facts.

technique of collecting information

statistics were amassed thru the following sources:

number one records: The device used for data series are in my opinion designed and structuredquestionnaire.

Secondary statistics: in this observe, secondary records collected through the employer newsletter, brochures, reviews, and so forth.

gear Used For facts evaluation: data amassed were tabulated and analyzed to set up the speculation and checking out speculation.the use of a statistical device likeChi-rectangular and ANOVAs

\section{RESULTS \& DISCUSSIONS}

Table 1 Demographics of Respondent

\begin{tabular}{|c|c|c|c|c|c|c|}
\hline Particulars & \multicolumn{5}{|c|}{ Number of respondents } & Total \\
\hline Gender & Female & \multicolumn{2}{|c|}{70} & Male & 110 & 180 \\
\hline \multirow[t]{2}{*}{ Age } & $20-30$ & \multicolumn{2}{|c|}{$31-40$} & $41-50$ & 51 and above & \multirow{2}{*}{180} \\
\hline & 45 & 65 & & 50 & 20 & \\
\hline \multirow[t]{2}{*}{$\begin{array}{l}\text { Monthly } \\
\text { Income }\end{array}$} & Less than 30000 & \multicolumn{2}{|c|}{$30000-50000$} & $50000-100000$ & $\begin{array}{ll}\text { More } & \text { than } \\
100000 & \end{array}$ & \multirow[t]{2}{*}{180} \\
\hline & 35 & 32 & & 38 & 75 & \\
\hline \multirow[t]{2}{*}{ Nature of Job } & \multicolumn{2}{|l|}{ Managerial } & \multicolumn{2}{|c|}{ Team lead } & Team member & \multirow[t]{2}{*}{180} \\
\hline & 75 & & 45 & & 60 & \\
\hline \multirow[t]{2}{*}{ Qualification } & \multicolumn{2}{|l|}{ Diploma } & \multicolumn{2}{|l|}{ UG } & PG & \multirow[t]{2}{*}{180} \\
\hline & 34 & & 45 & & 101 & \\
\hline \multirow[t]{2}{*}{ Work Nature } & \multicolumn{3}{|l|}{ Permanent } & \multicolumn{2}{|c|}{ Project based } & \multirow[t]{2}{*}{180} \\
\hline & \multicolumn{3}{|l|}{140} & \multicolumn{2}{|l|}{40} & \\
\hline
\end{tabular}

Bifurcation at the top of the profile of respondents describe that of all respondents 70 are female and 110 are male respondents. It is seen that most respondents fall elevated in class 31-40 years age group which is seen as a contestant crisp in the business and may have an encounter

almost every year. Besides the dominant undertaking a part of respondents P.G them as part of their instructive ability of around 101. In the natural addition of jobs in most of the respondents are permanently close to 140

\subsection{Results And Discussions}

Table 02: Level of agreement towards Employee Branding

\begin{tabular}{|c|c|c|c|c|c|c|c|c|c|c|c|}
\hline & \multicolumn{2}{|c|}{$\mathbf{S A}$} & \multicolumn{2}{|l|}{$\mathbf{A}$} & \multicolumn{2}{|c|}{ NAND } & \multicolumn{2}{|l|}{ D } & \multicolumn{2}{|c|}{ SD } & \multirow{2}{*}{ Total } \\
\hline & $\mathbf{N}$ & $\%$ & $\mathbf{N}$ & $\%$ & $\mathbf{N}$ & $\%$ & $\mathbf{N}$ & $\%$ & $\mathbf{N}$ & $\%$ & \\
\hline The organization defined employee value proposition & 66 & 37 & 34 & 19 & 24 & 13 & 16 & 9 & 40 & 22 & 180 \\
\hline $\begin{array}{c}\text { The talented employees opinion related to decisions on any } \\
\text { kind of matter related to their area of expertise }\end{array}$ & 60 & 33 & 34 & 19 & 8 & 4 & 30 & 17 & 48 & 27 & 180 \\
\hline $\begin{array}{c}\text { The organization Feature employee stories on your company } \\
\text { profiles }\end{array}$ & 89 & 49 & 33 & 18 & 14 & 8 & 14 & 8 & 30 & 17 & 180 \\
\hline $\begin{array}{l}\text { The top level managers focus in the overall development of } \\
\text { the potential leaders }\end{array}$ & 65 & 36 & 45 & 25 & 33 & 18 & 17 & 9 & 20 & 11 & 180 \\
\hline Organizations turn employees into brand ambassadors & 83 & 46 & 6 & 3 & 54 & 30 & 36 & 20 & 1 & 1 & 180 \\
\hline
\end{tabular}


it's miles seen from the above table that larger part respondents unequivocally concur with the thing of "The association characteristic employee testimonies for your corporation profiles, corporations rework representatives into emblem represetatives, The affiliation characterised employee incentive. Which implies that the representatives in the association are pleased about the way wherein they may be marked.

Table 03: Level of agreement towards Talent Acquisition

\begin{tabular}{|c|c|c|c|c|c|c|c|c|c|c|c|}
\hline & \multicolumn{2}{|l|}{ SA } & \multicolumn{2}{|l|}{$\mathbf{A}$} & \multicolumn{2}{|c|}{ NAND } & \multicolumn{2}{|l|}{ D } & \multicolumn{2}{|l|}{ SD } & \multirow{2}{*}{ Total } \\
\hline & $\mathbf{N}$ & $\%$ & $\mathbf{N}$ & $\%$ & $\mathbf{N}$ & $\%$ & $\mathbf{N}$ & $\%$ & $\mathbf{N}$ & $\%$ & \\
\hline The organization tracks the costs involved in the hiring process & 50 & 28 & 21 & 12 & 45 & 25 & 34 & 19 & 30 & 17 & 180 \\
\hline $\begin{array}{l}\text { The organizational website is a great marketing tool not just to } \\
\text { attract customers but also job candidates }\end{array}$ & 65 & 36 & 47 & 26 & 4 & 2 & 40 & 22 & 24 & 13 & 180 \\
\hline $\begin{array}{l}\text { The recruitment process is ensured to Eliminate hiring faults or } \\
\text { errors }\end{array}$ & 79 & 44 & 43 & 24 & 3 & 2 & 30 & 17 & 25 & 14 & 180 \\
\hline $\begin{array}{l}\text { The organization collects quick feedback from candidates that } \\
\text { appear for interviews, to help improve recruitment process }\end{array}$ & 50 & 28 & 45 & 25 & 20 & 11 & 30 & 17 & 35 & 19 & 180 \\
\hline $\begin{array}{c}\text { Brand image of an organization among the professionals and its } \\
\text { reputation attracts the best talent in industry towards your } \\
\text { organization }\end{array}$ & 54 & 30 & 34 & 19 & 2 & 1 & 54 & 30 & 36 & 20 & 180 \\
\hline
\end{tabular}

this can be seen from the desk above that most people of respondents consider the issue of "The recruitment manner is ensured from dispose of lease a mistake or error, organization's internet site is a remarkable advertising tool no longer handiest to attract clients but also prospective personnel, the emblem photo of the agency amongst experts and its recognition attract the great expertise within the enterprise on your business enterprise. The above table actually defined that the expertise acquisition manner within the organisation is best.

Table : 4 Showing ANOVA (Analysis of Variance) between factors of Employee Branding and the Talent Management

Enable us to test for the significance of the differences among more than two samples means.

\begin{tabular}{|c|l|l|l|l|}
\hline $\begin{array}{c}\text { Statistical } \\
\text { Variables }\end{array}$ & Count & Sum & Average & Variance \\
\hline $\begin{array}{c}\text { Employee Value } \\
\text { Proposition }\end{array}$ & 52 & 3684 & 16.087 & 7.212 \\
\hline $\begin{array}{c}\text { Succession } \\
\text { Planning }\end{array}$ & 52 & 3666 & 16.009 & 6.386 \\
\hline $\begin{array}{c}\text { Creative } \\
\text { Environment at } \\
\text { Work Place }\end{array}$ & 52 & 3166 & 13.825 & 6.759 \\
\hline $\begin{array}{c}\text { Training and } \\
\text { Development }\end{array}$ & 52 & 3052 & 13.328 & 3.976 \\
\hline $\begin{array}{c}\text { Employee - } \\
\text { Employer } \\
\text { Relationship } \\
\text { Management }\end{array}$ & 52 & 3733 & 16.301 & 7.597 \\
\hline
\end{tabular}

ANOVA

\begin{tabular}{|c|c|c|c|c|c|c|}
\hline $\begin{array}{c}\text { Source } \\
\text { of } \\
\text { Variati } \\
\text { on } \\
\end{array}$ & ss & $d f$ & $M S$ & $F$ & $\begin{array}{l}P \text { - } \\
\text { val } \\
\text { ue }\end{array}$ & $\begin{array}{c}F \\
\text { crit }\end{array}$ \\
\hline $\begin{array}{c}\text { Betwee } \\
\text { n } \\
\text { Group } \\
\text { s } \\
\end{array}$ & $\begin{array}{c}2792.10 \\
4\end{array}$ & 7.000 & $\begin{array}{c}398.8 \\
72\end{array}$ & $\begin{array}{c}72.7 \\
59\end{array}$ & $\begin{array}{c}0.0 \\
00\end{array}$ & $\begin{array}{l}2.0 \\
15\end{array}$ \\
\hline $\begin{array}{c}\text { Within } \\
\text { Group } \\
\text { s }\end{array}$ & $\begin{array}{c}9999.39 \\
7\end{array}$ & $\begin{array}{c}1824.0 \\
00\end{array}$ & 5.482 & & & \\
\hline Total & $\begin{array}{c}12791.5 \\
02\end{array}$ & $\begin{array}{c}1831.0 \\
00\end{array}$ & & & & \\
\hline
\end{tabular}

Based on the observation, the values from the above Table is: F( Observed) Value $>$ F ( Critical) Value

ie the discovered values lie outside the reception area and use it, we are able to be able to make conclusions about whether our samples were taken from the populace have the equal imply.

\section{A $P$ price <zero.05}

it could be concluded that the common price of element brandingand acquisitionare worker skills is not the identical and they may be now not given equal importance in the IT business enterprise.

\subsection{Hypothesis test:}

H0: There is no significant association between Employee Branding and the Talent Management

$\mathrm{H}_{1:}$ There is a significant association between Employee Branding and the Talent Management 
Table 5: Showing association between Employee Branding and the Talent Management

\begin{tabular}{|c|c|c|c|c|c|}
\hline $\begin{array}{l}\text { Employee Branding / } \\
\text { Talent Management }\end{array}$ & High & Medium & Low & Total & $\begin{array}{ll}\text { Chi square } \\
\text { test }\end{array}$ \\
\hline Succession Planning & 12 & 5 & 5 & 22 & \multirow{6}{*}{$\chi 2=182.80$} \\
\hline Recognition & 15 & 10 & 10 & 35 & \\
\hline Creative Environment at Work Place & 14 & 21 & 30 & 65 & \\
\hline Training and Development & 18 & 21 & 16 & 55 & \\
\hline $\begin{array}{c}\text { Employee - Employer Relationship } \\
\text { Management } \\
\end{array}$ & 24 & 33 & 12 & 69 & \\
\hline Total & 83 & 90 & 73 & 246 & \\
\hline
\end{tabular}

Interpretation: p-value less than 0.05 justifies null hypothesis to be rejected. This means alternate hypothesis that 'There is a significant association between Employee Branding and the Talent Management" need to be accepted.

\section{CONCLUSION:}

All in all, each and every affiliation has comprehended the importance of top rate, and preserve their primary potential within the marketplace to appearance after center. institutions should be a warfare of potential to seize the attention of a gifted body of workers. it's miles an potential the executives that lets in relates in enhancing consultant obligation, responsibility, maintenance, improvement upgraded self murmur definitive imprint. Marking and expertise management representatives are scanty breaking factor the association to hold to make and resources are relied upon to streamline capability compelling pleasure of the number one cause and execution. The techniques need to be dealt with within the affiliation to build the immoderate floor. HR branch need to at the start attention on capacity look at approach association calls for to run the application and get prepared. capability the executives frameworks furthermore want to agree with full-size alternatives modern. It turned into a exquisite test the ability of the board is not essential for the capability to provide, but it is for the capacity to interface the board practices with corporation method.

\section{REFERENCES}

1. Shaw, J. D., Gupta, N., and Delery, J. E. (2005) conceptualization .alternative of the connection among intentional turnover and authoritative execution. Institute of control journal, 48, 50-sixty eight.

2. - Snell A. (2007). "critical functionality the board, Human resource control: the connection of training and system property with an powerful career inside the affiliation of China", Int. J. Human resource management 179 September 1531 to 1546

3. - Stockley D. 2007.expertise the executives concept - the definition and rationalization [online] to be had of http://derekstockley.Com.Au/bulletins $\quad$ 05/020 talentmanagement. Html

4. - The Society for Human useful resource control (SHRM) 2012 worker pride and Engagement: How employees managing Uncertainty, October 2012, forty one.

5. - Tarique, I. And Schuler, R. (2010), a worldwide functionality the executives: Literature audit, integrative device, and hints for further investigate. commercial enterprise world magazine, forty five, 122-133.
6. - CIPD (2010). The yearly evaluate record: mastering and capability advancement. Recovered may additionally 25

2013Fromhttp:/www.Cipd.Co.uk/NR/rdonlyres/BC060D D1-EEA7-4929-

91421AD733F95E7/5215Learningtalentdevelopmentsurv eyreport.Pdf-every year

7. - Collings, D. what's more, Mellahi, k. (2009). Key capacity the executives: an audit and studies motivation. Human useful resource control evaluation. 19, 304-313.

8. - cross, R. And Prusak, L. (2002) The folks that make the association to prevent or cross. Harvard commercial enterprise overview, eighty, 104-112. 